\title{
A comparison of settlement plate types for experiments on the recruitment of scleractinian corals
}

\author{
Vicki J. Harriott* \& David A. Fisk** \\ Sir George Fisher Centre for Tropical Marine Studies, James Cook University, Townsville 4812, Australia
}

\begin{abstract}
Eight substratum types, covering the range normally used for experiments on recruitment of scleractinian corals, were compared for cost, convenience, ability to attract recruits, and taxonomic composition of recruits. Plates varied significantly in number and types of recruits, indicating that studies utilizing different types of settlement surfaces cannot be compared directly to one another. Recruitment patterns also varied between forereef and backreef study sites, adding to the growing list of factors that contribute to variability in scleractinian recruitment.
\end{abstract}

\section{INTRODUCTION}

The abundance of studies on coral recruitment patterns in recent years has done much to highlight aspects of coral reproductive strategies and population dynamics. Some studies (Birkeland 1977, Birkeland et al. 1982, Sammarco \& Carleton 1982, Wallace \& Bull 1982, Harriott 1983a, 1985. Sammarco 1983, Alino et al. 1985, Babcock 1985, 1986, Fitzhardinge 1985, Wallace $1985 \mathrm{a}$, b) have utilized settlement plates, while others have recorded recruitment in the field onto natural substrata (Bak \& Engel 1979, Rylaarsdam 1983, Sakai \& Yamazato 1984). The latter studies are restricted to observations of corals at visible size, which are generally at least $1 \mathrm{yr}$ post-settlement (Wallace 1983, Harriott 1985).

A problem inherent in the comparison of the results of recruitment studies is that almost every author has used a different settlement surface, and there are few studies directly comparing recruitment on different surfaces.

Surfaces previously used in coral recruitment experiments include artificial substrata not generally found in the reef environment such as glass (Stephenson 1931, Harrigan 1972, Lewis 1974, Goreau et al. 1981,

Present addresses:

- Great Barrier Reef Marine Park Authority, PO Box 1379,

Townsville 4810, Australia

- Reef Research and Information Services, PO Box 5348,

Townsville M.C. 4810, Australia
Coles 1985), terracotta or ceramic tiles (Vaughan 1959 [cited in Lewis 1974], Brock 1979, Baggett \& Bright 1985), PVC surfaces or plastic Petri dishes (Birkeland 1977. Birkeland et al. 1982, Wallace \& Bull 1982, Harriott 1983a), concrete blocks (Fitzhardinge 1985); as weil as other surfaces similar to those found naturally in the field, such as tridacnid clam shells (Babcock 1986), slices of coral block (Harriott 1983b, 1985, Sammarco 1983, Alino et al. 1985, Babcock 1985, 1986), and the outer surface of pieces of dead coral (Harrigan 1972, Lewis 1974, Sammarco \& Carleton 1982, Wallace \& Bull 1982, Rylaarsdam 1983, Wallace 1983, 1985a, b).

Most coral recruitment studies have been limited to one field site and there is little information on the variation in recruitment patterns between different reef sites, although Baggett \& Bright (1985) reported significant differences in recruitment to settlement racks only $5 \mathrm{~m}$ apart.

This report assesses variation in recruitment patterns of scleractinian corals on 8 different substratum types in a number of forereef and backreef sites. The study was designed to aid in the selection of the best settlement surface (with respect to convenience, cost and characteristics in attracting recruits) for future experiments.

\section{METHODS}

Settlement plates were placed at 6 sites at Middle Cay Reef $\left(145^{\circ} 59^{\prime} \mathrm{E}, 16^{\circ} 39^{\prime} \mathrm{S}\right)$ in the central Great 
Barrier Reef. Coral cover at Middle Cay Reef is approximately 20 to $40 \%$, and the reef was apparently unaffected by predation by the crown of thorns starfish in the late 1970's, unlike most of the reefs in the region.

Three racks were placed in sandy pools separated by distances of 20 to $40 \mathrm{~m}$ in the gently sloping forereef slope, and 3 were placed adjacent to small patch reefs separated by 15 to $30 \mathrm{~m}$ on the sandy backreef area. In all cases water depth was approximately $4 \mathrm{~m}$ at low tide.

Racks were made from galvanised fencing mesh with sides folded to form a support so that the top of the rack was raised about $15 \mathrm{~cm}$ above the substratum. Racks were attached to the substratum with stakes. Each rack initially contained 8 different settlement surfaces, listed here in approximate order of increasing surface relief.

(a) Plastic Petri dishes, $9 \mathrm{~cm}$ diameter.

(b) Ceramic wall tiles with the glazed surface outermost.

(c) Ceramic wall tiles with the unglazed surface outermost.

(d) Slices of massive Porites spp. cut with a diamond saw. The internal structure of Porites gives a finegrained surface with little textural relief.

(e) Slices of massive Platygyra spp. cut with a diamond saw. This faviid coral has an internal skeletal structure with much larger spaces than the Porites skeleton.

(f) Thick branches of Acropora palifera. The external skeleton has typical Acropora polyps but has very few thick branches.

(g) The outer surface of Platygyra spp. A meandroid coral with polyps up to $5 \mathrm{~mm}$ deep. The colony was cut so that there was one smooth cut surface and one outer surface.

(h) Branches of Pocillopora eydouxi. This coral is covered with raised verrucae 3 to $4 \mathrm{~mm}$ high, and its suitability for coral settlement was described by Wallace \& Bull (1982).

Several of these surfaces have been used in previous studies, and cover the range of surface types often used in coral settlement experiments.

For the first 5 plate types listed above, plates were placed above and below the weldmesh rack and were bolted together through holes drilled in the plates, except for the Petri dishes which were attached together by wire rather than bolts (Fig. 1). There were only a limited number of pieces of the outer Platygyra spp. surface available, and since earlier studies had shown preferential settlement on lower rather than upper surfaces (Harriott 1985), we attached the available pieces under the rack by wire with the outer coral surface lowermost (Fig. 1). The morphology of the pieces of Acropora palifera and Pocillopora eydouxi

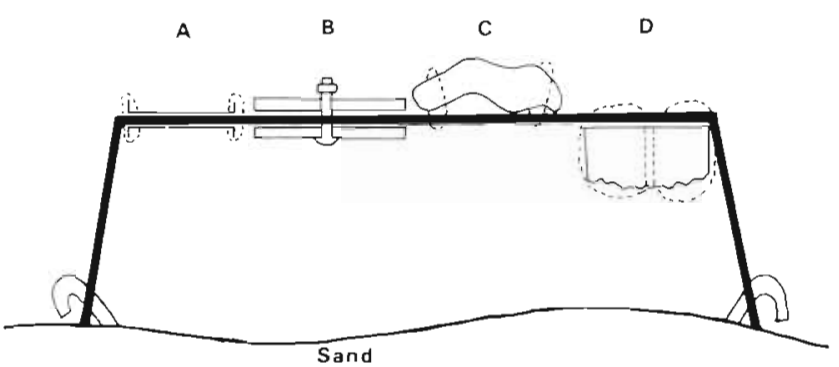

Fig. 1. Cross-section of a settlement rack showing the methods of attachment for different plate types. A: attached above and below the rack by wire (Petri dishes); B: bolted above and below the rack (ceramic tiles and coral slices); $\mathrm{C}$ : tied to the top of the rack (Pocillopora eydouxi and Acropora palifera); D: tied to the lower surface of the rack (outer Platygyra spp. surface)

prevented their being bolted to the rack, so they were attached to the top of the rack by wire. Because of the irregular shapes of the coral pieces, this meant that there were still upper and lower surfaces available for settlement (Fig. 1).

Racks were placed in the field on 18 October 1985 and collected on 10 March 1986, a period of approximately $20 \mathrm{wk}$ during the time of the predominant seasonal spring/summer spawning on the Great Barrier Reef (Harriott 1983c, Harrison et al. 1984, Willis et al. 1985, Babcock et al. 1986). This also corresponds with the period of maximum coral recruitment on the Great Barrier Reef (Wallace \& Bull 1982, Harriott 1985, Wallace 1985a, b).

On collection, the plates were labelled, bleached in a chlorine solution and air-dried. Plates were searched using a dissection microscope, and all spat were marked and counted. Only the horizontal surfaces of plates were searched because not all plates had vertical surfaces and the edges of coral slices were irregular in size and texture. Plates were searched again at a higher power and the location and identification of all spat were recorded on a tracing of the outline of the plate shape. The number of polyps and largest diameter of each colony was recorded, and the area of each settlement plate was measured from the tracing using a planimeter.

Spat were identified as belonging to the families Acroporidae, Pocilloporidae and Poritidae, with the remainder of the spat, and those too small to identify, being designated as others.

\section{RESULTS}

\section{Plate preparation time and cost}

Of the 8 surfaces tested, Petri dishes and tiles have minimal preparation time. Both can be purchased readily, and are inexpensive. 
The coral branches (Pocillopora eydouxi and Acropora palifera) must be collected from the field but have little preparation time. The total time and costs will depend on the accessibility of suitable coral colonies.

For blocks cut from massive coral colonies, collection times and costs are similar to coral branches, but there is the additional time and effort of cutting the massive coral colonies into blocks of the required size.

\section{Searching effort}

The substratum types tested varied widely in their ease of searching. Some of the large coral pieces were hard to manipulate under the microscope and it was

Table 1. Comparison of the number of spat counted by dissection microscope on 8 types of settlement plate at low power, and on a second count at a higher power

\begin{tabular}{|lrcc|}
\hline \multicolumn{1}{|c}{ Surface type } & $\begin{array}{c}\text { First } \\
\text { count }\end{array}$ & $\begin{array}{c}\text { Second } \\
\text { count }\end{array}$ & $\begin{array}{c}\% \text { seen on } \\
\text { first count }\end{array}$ \\
\hline Petri dishes & 101 & 125 & $81 \%$ \\
Glazed tiles & 356 & 396 & $90 \%$ \\
Unglazed tiles & 364 & 428 & $85 \%$ \\
Cut Porites spp. & 241 & 295 & $82 \%$ \\
Cut Platygyra spp. & 233 & 323 & $72 \%$ \\
Acropora palifera & 76 & 96 & $79 \%$ \\
Outer Platygyra spp. & 115 & 169 & $68 \%$ \\
Pocillopora eydouxi & 188 & 263 & $71 \%$ \\
\hline
\end{tabular}

difficult to search the complex coral surfaces. Small spat were often сгуptic in the interseptal spaces.

To quantify the differences in the ease with which coral spat could be detected we compared the number of spat counted at low power and in a subsequent search at a higher power (Table 1). The percentage of spat seen on an initial scrutiny ranged from 68 to $90 \%$, with tiles the easiest surface to search and the outer coral surfaces the most difficult.

\section{Abundance and density of spat}

Some plates were lost from 2 of the racks, probably during the passage of Cyclone Winifred close to the area in February 1986. Because of the reduced sample sizes for 2 of the plate types, results for abundance and density of spat were analysed only for the plate types with complete data sets (Table 2).

In the analysis of abundance of spat, the number of spat on each plate or pair of plates bolted together was counted for each of the 3 forereef and 3 backreef racks (Table 2). A 2-way analysis of variance showed that the abundance of spat was significantly dependent both on plate type, and on whether the plates were located in the forereef or backreef zone (Table 3). Of the 6 surfaces analysed, tiles had the largest total number of spat, the various coral surfaces an intermediate number, and Petri dishes the lowest numbers (Table 2). For the 2 surfaces not included in the analysis, the numbers of spat on the Platygyra spp. plates was com-

Table 2. Spat abundance, and density of spat per $\mathrm{cm}^{2}$ on the lowermost surface (in brackets), on forereef and backreef racks for 8 plate types. -: plates lost

\begin{tabular}{|c|c|c|c|c|c|c|c|c|}
\hline \multirow[t]{2}{*}{ Plate type } & \multicolumn{4}{|c|}{ Forereef } & \multicolumn{4}{|c|}{ Backreef } \\
\hline & Rack 1 & Rack 2 & Rack 3 & Mean & Rack 1 & Rack 2 & Rack 3 & Mean \\
\hline Petri dishes & $\begin{array}{c}26 \\
(0.18)\end{array}$ & $\begin{array}{c}5 \\
(0.03)\end{array}$ & $\begin{array}{c}23 \\
(0.16)\end{array}$ & $\begin{array}{c}18 \\
(0.12)\end{array}$ & $\begin{array}{c}33 \\
(0.14)\end{array}$ & $\begin{array}{c}7 \\
(0.01)\end{array}$ & $\begin{array}{c}19 \\
(0.07)\end{array}$ & $\begin{array}{c}19 \\
(0.07)\end{array}$ \\
\hline Glazed tiles & $\begin{array}{c}62 \\
(0.07)\end{array}$ & $\begin{array}{c}41 \\
(0.09)\end{array}$ & $\begin{array}{c}43 \\
(0.05)\end{array}$ & $\begin{array}{c}49 \\
(0.07)\end{array}$ & $\begin{array}{c}90 \\
(0.05)\end{array}$ & $\begin{array}{c}30 \\
(0.05)\end{array}$ & $\begin{array}{l}100 \\
(0.02)\end{array}$ & $\begin{array}{c}73 \\
(0.04)\end{array}$ \\
\hline Unglazed tiles & $\begin{array}{c}60 \\
(0.13)\end{array}$ & $\begin{array}{c}28 \\
(0.07)\end{array}$ & $\begin{array}{c}26 \\
(0.15)\end{array}$ & $\begin{array}{c}38 \\
(0.12)\end{array}$ & $\begin{array}{c}112 \\
(0.10)\end{array}$ & $\begin{array}{c}85 \\
(0.21)\end{array}$ & $\begin{array}{c}109 \\
(0.17)\end{array}$ & $\begin{array}{c}102 \\
(0.16)\end{array}$ \\
\hline Cut Porites spp. & $\begin{array}{c}17 \\
(0.06)\end{array}$ & $\begin{array}{c}15 \\
(0.07)\end{array}$ & $\begin{array}{c}44 \\
(0.30)\end{array}$ & $\begin{array}{c}25 \\
(0.14)\end{array}$ & $\begin{array}{c}95 \\
(0.17)\end{array}$ & $\begin{array}{c}57 \\
(0.29)\end{array}$ & $\begin{array}{c}63 \\
(0.11)\end{array}$ & $\begin{array}{c}72 \\
(0.19)\end{array}$ \\
\hline Cut Platygyra spp. & $\begin{array}{c}38 \\
(0.14)\end{array}$ & $\begin{array}{c}44 \\
(0.24)\end{array}$ & $\begin{array}{c}29 \\
(0.26)\end{array}$ & $\begin{array}{c}37 \\
(0.21)\end{array}$ & $\begin{array}{c}81 \\
(0.34)\end{array}$ & $\begin{array}{c}41 \\
(0.21)\end{array}$ & $\begin{array}{c}57 \\
(0.28)\end{array}$ & $\begin{array}{c}60 \\
(0.28)\end{array}$ \\
\hline Pocillopora eydouxi & $\begin{array}{c}37 \\
(0.29)\end{array}$ & $\begin{array}{c}31 \\
(0.19)\end{array}$ & $\begin{array}{c}27 \\
(0.16)\end{array}$ & $\begin{array}{c}32 \\
(0.21)\end{array}$ & $\begin{array}{c}64 \\
(0.49)\end{array}$ & $\begin{array}{c}51 \\
(0.36)\end{array}$ & $\begin{array}{c}50 \\
(0.49)\end{array}$ & $\begin{array}{c}55 \\
(0.45)\end{array}$ \\
\hline Acropora palifera & $\begin{array}{c}6 \\
(0.07)\end{array}$ & $\begin{array}{c}3 \\
(0.02)\end{array}$ & - & $\begin{array}{c}5 \\
(0.05)\end{array}$ & $\begin{array}{c}50 \\
(0.37)\end{array}$ & $\begin{array}{c}37 \\
(0.26)\end{array}$ & - & $\begin{array}{c}44 \\
(0.32)\end{array}$ \\
\hline Outer Platygyra spp. & $\begin{array}{c}25 \\
(0.35)\end{array}$ & $\begin{array}{c}27 \\
(0.39)\end{array}$ & $\begin{array}{c}42 \\
(0.42)\end{array}$ & $\begin{array}{c}31 \\
(0.39)\end{array}$ & $\begin{array}{c}28 \\
(0.47)\end{array}$ & $\begin{array}{c}33 \\
(0.43)\end{array}$ & $\begin{array}{l}- \\
-\end{array}$ & $\begin{array}{c}31 \\
(0.45)\end{array}$ \\
\hline
\end{tabular}


Table 3. Results of an analysis of variance for spat abundance per plate set for 6 plate types in forereef and backreef zones

\begin{tabular}{lrrl|}
\hline \multicolumn{1}{c}{ Factor } & $\mathrm{d} f$ & F-ratio & \multicolumn{1}{c|}{$\mathrm{p}(\mathrm{F})$} \\
\hline Reef zone & 1 & 27.22 & $2.4 \times 10^{-5}$ \\
Plate type & 5 & 5.97 & 0.001 \\
Interaction & 5 & 2.30 & 0.08 \\
Error & 24 & & \\
\hline
\end{tabular}

parable with other coral surfaces, while those on Acropora palifera were very low at the forereef site.

Recruitment was greater to the lower surface than the upper surface for all plate types. On the Petri dishes, 17 spat (15\% of the total) recruited to the upper surface, and these were found almost exclusively on the vertical lip of the dish. On the other 39 top plates, only 7 corals had recruited to the upper surface, of a total of over 2000 .

In all cases where pairs of plates were bolted together, significant recruitment occurred on the surfaces forming the approximately $3 \mathrm{~mm}$ wide gap between the pairs of plates. An analysis of the percentage of recruits that had settled in the gap, for the 5 plate types in which such a gap was available, indicated that the percentage of recruits in the gap was dependent both on plate type and on whether the plates were in the forereef or backreef zone (Table 4). The percentage ranged from a mean of $30.8 \%$ for forereef Petri dishes to $79.5 \%$ for backreef tiles with glazed surface outermost (Fig. 2).

Because of the variation in size of plates, and the types of surface available on each, we standardised the comparison of different plate types by comparing density of recruits $\left(\mathrm{cm}^{-2}\right)$ on the lowermost surface only of all plate types in the forereef and backreef zones. There was a significant interaction between the factors reef zone and plate type (Table 5), indicating that the relative density of spat on the different plate types varied between the reef zones. When we examine the results for the 2 zones separately

Table 4. Results of an analysis of variance for the percentage of all corals found on the plate surfaces forming the gap between the top and bottom plate for the 5 plate types in which a gap was present, analysed for forereef and backreef zones. Percentage data were arcsin transformed (Sokal \& Rohlf 1969)

\begin{tabular}{lrcl|}
\hline \multicolumn{1}{c}{ Factor } & $\mathrm{df}$ & F-ratio & $\mathrm{p}(\mathrm{F})$ \\
\hline Reef zone & 1 & 8.56 & $8.4 \times 10^{-3}$ \\
Plate type & 4 & 4.21 & 0.01 \\
Interaction & 4 & 0.7 & 0.99 \\
Error & 20 & & \\
\hline
\end{tabular}

Table 5. Results of an analysis of variance for spat density per $\mathrm{cm}^{2}$ on the lowermost surface only for 6 plate types in torereef and backreef zones.

\begin{tabular}{|lrrl|}
\hline Factor & df & F-ratio & p (F) \\
\hline Reef zone & 1 & 4.56 & 0.04 \\
Plate type & 5 & 11.77 & $7.9 \times 10^{-6}$ \\
Interaction & 5 & 2.92 & 0.03 \\
Error & 24 & & \\
\hline
\end{tabular}

(Table 2), it can be seen that in each zone there was high density recruitment on Pocillopora eydouxi and cut Platygyra spp. plates, moderate density on Porites spp. plates, and low density on tiles and Petri dishes. The density on outer Platygyra spp. surfaces was the highest of all the plates examined.

\section{Taxonomic composition}

Acroporids comprised $32 \%$ of the spat in the forereef and $63 \%$ in the backreef, while pocilloporids comprised $41 \%$ of spat in the forereef and $21 \%$ in the backreef. Less than $2 \%$ of all spat were poritids, and no other identifiable group formed more than $1 \%$ of the total. The 19 to $25 \%$ of spat classed as unidentified included many which were too small to distinguish with any certainty $(<0.5 \mathrm{~mm}$ diameter), as well as those that were damaged or eroded, and those which were distinctive but could not be assigned to a particular group.

There were no major differences in the relative frequencies of the major taxa on each rack within a reef zone (i.e. within the forereef and within the backreef). When the recruits on the different plate types of each settlement rack were pooled to give an overall figure for each rack, contingency table analyses showed that the relative abundance of the major taxa was not significantly different for the replicate racks within the forereef and backreef zones $(p<0.01)$.

Analysis of the number of acroporid and pocilloporid recruits on each plate type for the 3 racks pooled in each zone indicate that there were 2 to 10 times as many acroporids on the backreef than the forereef racks, while the number of pocilloporids was similar at the 2 zones (Table 6).

The analysis of the effect of plate type and reef zone on the percentage of pocilloporids and acroporids showed a significant interaction between the factors reef zone and plate type for both pocilloporids and acroporids (Table 7). An examination of the results for different plate types for each zone shows that there was generally a greater proportion of pocilloporids in the forereef than the backreef, while the reverse was true 
Table 6. Number of acroporid and pocilloporid recruits on each of 6 plate types. Racks within the forereef zone and backreef zone are pooled

\begin{tabular}{|c|c|c|c|c|}
\hline \multirow[t]{2}{*}{ Plate type } & \multicolumn{2}{|c|}{ Forereef } & \multicolumn{2}{|c|}{ Backreef } \\
\hline & $\begin{array}{l}\text { Acro- } \\
\text { porid }\end{array}$ & $\begin{array}{l}\text { Pocillo- } \\
\text { porid }\end{array}$ & $\begin{array}{l}\text { Acro- } \\
\text { porid }\end{array}$ & $\begin{array}{l}\text { Pocillo- } \\
\text { porid }\end{array}$ \\
\hline Petri dishes & 17 & 26 & 36 & 13 \\
\hline Glazed tiles outer & 31 & 91 & 128 & 53 \\
\hline Unglazed tiles outer & 17 & 77 & 180 & 68 \\
\hline Cut Porites spp. & 16 & 27 & 154 & 27 \\
\hline Cut Platygyra spp. & 42 & 38 & 94 & 46 \\
\hline Pocillopora eydouxi & 45 & 16 & 99 & 32 \\
\hline
\end{tabular}

of acroporids. In the forereef plates there was a clear tendency for the percentage of pocilloporids to decline from the smoother to the more textured surfaces, but no clear pattern emerged for the acroporids.

To determine whether the 'gap' habitat attracted different types of spat from the upper or lower surfaces, we analysed the percentage of pocilloporids and acroporids on 4 plate types where a gap was present (Fig. 2) looking for the effects of the factors reef zone, plate type and position within a plate set on the taxonomic composition. Results were analysed for the 2 positions where sample sizes were sufficient to give good data, i.e. under the top plate and under the bottom plate. There were insufficient recruits on the

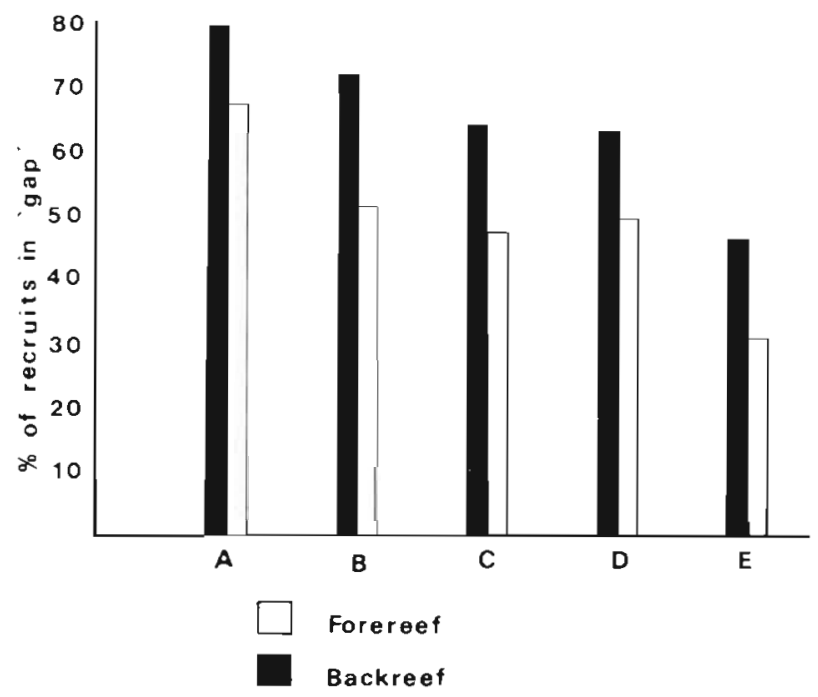

Fig. 2. Percentage of recruits found in the 'gap' habitat for the 5 plate types attached in pairs, at forereef and backreef sites. A: Ceramic tiles with glazed surface outermost; B: ceramic tiles with unglazed surface outermost; C: slices of Platygyra sp.; D: slices of Porites; E: Petri dishes

Petri dishes to include them in this analysis. Only reef zone had a significant effect on the percentage of pocilloporids and acroporids (Table 8). The location within a plate set was not a significant factor, indicating a similarity between the types of recruits in the gap and on the lowermost surface.

Table 7. Results of an analysis of variance for the percentage of pocilloporids and acroporids on 5 plate types in forereet and backreef areas Percentage data were arcsin transformed (Sokal \& Rohlf 1969)

\begin{tabular}{|c|c|c|c|c|c|c|}
\hline \multirow[t]{2}{*}{ Factor } & \multicolumn{3}{|c|}{ Pocilloporids } & \multicolumn{3}{|c|}{ Acroporids } \\
\hline & $\mathrm{df}$ & F-ratio & $\mathrm{p}(\mathrm{F})$ & $\mathrm{df}$ & F-ratio & $\mathrm{p}(\mathrm{F})$ \\
\hline Reef zone & 1 & 30.32 & $2.1 \times 10^{-5}$ & 1 & 92.13 & $-1.2 \times 10^{-7}$ \\
\hline Plate type & 4 & 5.86 & $2.7 \times 10^{-3}$ & 4 & 2.95 & 0.05 \\
\hline Interaction & 4 & 5.05 & $5.6 \times 10^{-3}$ & 4 & 7.04 & $1.0 \times 10^{-3}$ \\
\hline Error & 20 & & & 20 & & \\
\hline
\end{tabular}

Table 8. Results of a 3-way analysis of variance for the effect on the percentage of pocilloporids and acroporids under the top plate and under the bottom plate (in pairs of plates bolted together) of the factors reef zone and plate type. Percentage data were arcsin transformed (Sokal \& Rohlf 1969)

\begin{tabular}{|c|c|c|c|c|c|c|}
\hline \multirow[t]{2}{*}{ Factor } & \multicolumn{3}{|c|}{ Pocilloporids } & \multicolumn{3}{|c|}{ Acroporids } \\
\hline & df & F-ratio & $\mathrm{p}(\mathrm{F})$ & $\mathrm{df}$ & F-ratio & $p(F)$ \\
\hline Reef zone (A) & 1 & 14.41 & $6.19 \times 10^{-4}$ & 1 & 37.25 & $7.7 \times 10^{-}$ \\
\hline Plate type (B) & 3 & 2.78 & 0.06 & 3 & 1.39 & 0.26 \\
\hline Location (C) & 1 & 14.84 & 0.80 & 1 & 2.70 & 0.11 \\
\hline \multicolumn{7}{|l|}{ Interaction } \\
\hline$A \times B$ & 3 & 1.11 & 0.36 & 3 & 2.25 & 0.10 \\
\hline$A \times C$ & 1 & 0.47 & 0.49 & 1 & 0.01 & 0.99 \\
\hline$B \times C$ & 3 & 1.68 & 0.19 & 3 & 2.87 & 0.051 \\
\hline$A \times B \times C$ & 3 & 0.49 & 0.69 & 3 & 0.24 & 0.87 \\
\hline Error & 32 & & & 32 & & \\
\hline
\end{tabular}




\section{Size frequency of spat}

Size frequency results for recruits were available for both colony diameter and number of polyps. The plots for the 2 variables resemble each other so we present here only results for the number of polyps. The number of polyps per colony was plotted for both pocilloporids and acroporids settling on 3 plate types (glazed tile, cut Platygyra spp., Pocillopora eydouxi; Fig. 3).

Two trends were apparent. First, for both taxa, the glazed tiles had more spat with large numbers of polyps than were found on the more textured coral surfaces. Second, on all surfaces the pocilloporids had more polyps per colony than acroporid colonies.

\section{DISCUSSION}

Scleractinian recruitment patterns on a mid-shelf reef of the central Great Barrier Reef varied both with reef zone (shallow forereef versus shallow backreef) and with the type of settlement plate used. These factors are additional to the list of factors that must already be taken into account when designing coral recruitment experiments; e.g. water depth, plate orientation (Birkeland 1977, Birkeland et al. 1982, Wallace \& Bull 1982, Harriott 1985, Wallace 1985a, b), reef type (Sammarco 1983), and degree of shelter of the plates (Wallace 1985a).

While Baggett \& Bright (1985) have previously reported within-site variation in recruitment patterns, this study is the first to investigate differences in replicated, widely-separated sites on a single reef. The higher recruitment in the backreef area compared to forereef reported here has also been found for 3 other nearby reefs (Harriott \& Fisk unpubl.), indicating a possible general pattern with respect to broad reef zones. The major difference between the forereef and backreef sites was the far greater abundance and density of acroporid recruits in the backreef, with other groups in relatively constant numbers. There is no indication from our general observations that differences in the surrounding coral community contribute to differences in local recruitment, and local current patterns are almost certainly involved (Harriott \& Fisk unpubi.).

The finding that recruitment patterns were strongly dependent on the type of settlement plates used means that care must be taken when comparing the results of studies using different types of settlement plates.

The use of 2 equal-sized plates as a sampling unit provides a standard gap habitat where large numbers of spat settle. The planulae appear to be showing a preference for a cryptic, low light micro-habitat for settlement, as has been previously described (Lewis

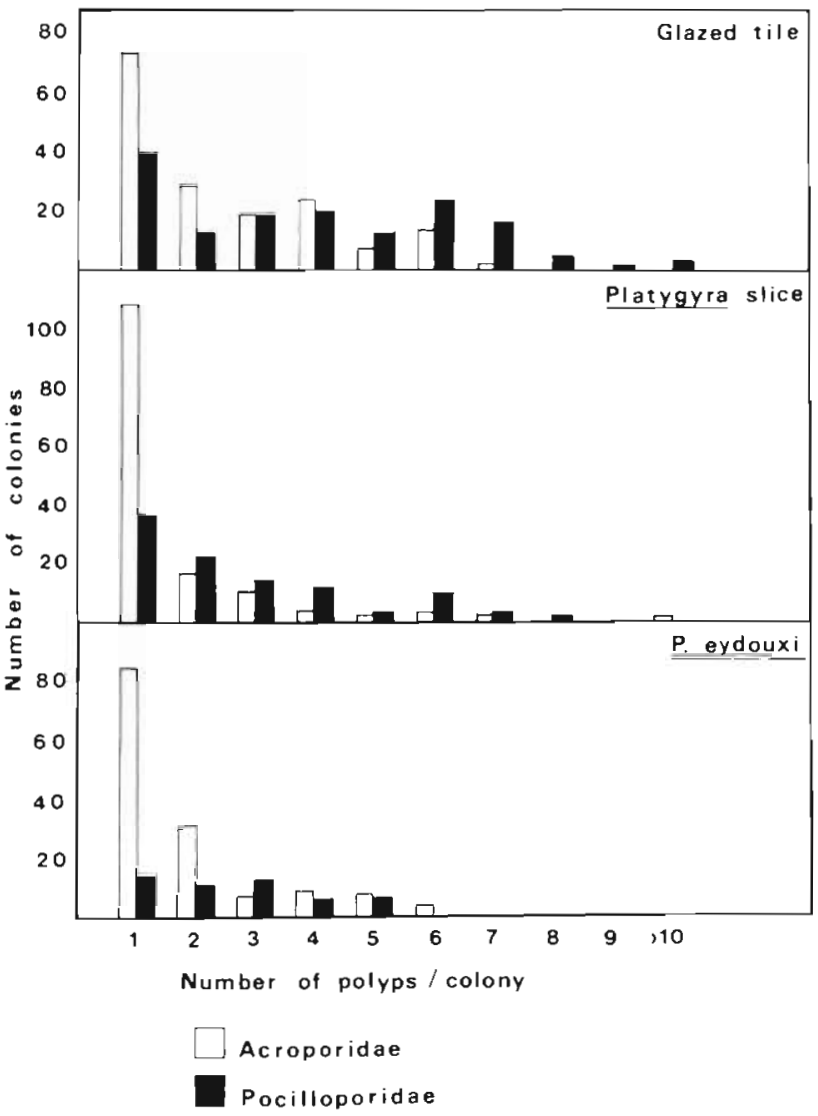

Fig. 3. Frequency distributions of the number of polyps per colony for coral recruits on 3 settlement surfaces. Sample sizes, mean number of polyps and standard error of the means are as follows. Acroporids on glazed tile: $\mathrm{n}=165$, mean $=$ 2.44, $\mathrm{SE}=0.13$; pocilloporids on glazed tile: $\mathrm{n}=146$, mean $=3.92, \mathrm{SE}=0.21 ;$ acroporids on Platygyra sp. slice: $\mathrm{n}=145$, mean $=1.62, \mathrm{SE}=0.12$; pocilloporids on Platygyra sp. slice: $\mathrm{n}=97$, mean $=2.67, \mathrm{SE}=0.19 ;$ acroporids on Pocillopora eydouxi: $\mathrm{n}=138$, mean $=1.82, \mathrm{SE}=0.11$, pocilloporids on P. eydouxi: $\mathrm{n}=46$, mean $=2.59, \mathrm{SE}=0.20$

1974, Harriott 1985). The gap habitat can be readily examined when the plates are separated and labelled.

We present here a description of the advantages and disadvantages of each surface. Recommendations are based on the assessments of preparation effort, ease of searching and number of spat collected.

(a) Petri dishes (plastic surface) were found to be unsatisfactory. They were often lost from racks (Wallace \& Bull 1982, Harriott 1983a), and they had the lowest recruitment of any surface in this study.

(b) Ceramic tiles attracted the largest numbers of spat when attached in pairs with a central gap. They are cheap, readily available, have minimal preparation, and provide a standard surface easily replicated within and between experiments. They were the easiest surface to search and are convenient to store. Their use requires no destruction of living corals. Colonies that settled on tiles were larger and had more 
polyps than those settling on more complex dead coral surfaces, possibly because the corals were unobstructed in their outward growth relative to those which settled in the interstices of the coral skeleton.

(c) Slices of dead coral are good surfaces for coral recruitment, but different types of coral varied in the number of recruits attracted. We found higher recruitment rate on faviid than on poritid coral slices; a similar result was reported by Babcock (1986). The main disadvantage of cut coral blocks is that they are laborious to produce, especially if identical units are required, and they require the removal of living coral colonies.

(d) The outer surface of Pocillopora eydouxi colonies gave the highest density of spat settlement on the lower surface, although the total number of recruits was lower than tiles, because of the absence of the 'gap' habitat. Plates made from Acropora palifera did not attract as many recruits as $P$. eydouxi plates. The plates require little preparation and provide a surface partly protected from the effects of predation and with a variety of textures and orientations. They have the advantage that they may reflect the type of habitat available to new recruits on the reef and thus be representative of the field situation. The disadvantages of this surface are: (1) that corals must be killed and the supply of the right type of coral might become limited in the course of a long experiment; (2) the irregular size and shape of the surface gives uneven recruitment over the surface and, when subsampled to obtain a uniform sample size, some erior may be introduced; (3) few species are found in all biogeographic regions reducing the chance of consistency between different studies; and (4) the $P$. eydouxi plates were among the most difficult to search, and much practice would be needed to find most colonies.

Overall, we found the best surface for recruitment studies at this site to be ceramic tiles because of their convenience, ease of searching, non-destructiveness, and the abundance of spat they attract. In our future experiments, we intend to use pairs of tiles (each $15 \times 15 \mathrm{~cm}$ ), bolted together in both horizontal and vertical orientations, with the unglazed surfaces lowermost for the tiles attached horizontally. We recommend the use of vertically oriented tiles in addition to the horizontal ones because our recruitment studies in an inshore fringing reef environment have indicated a preference for settlement on vertical substrata in that habitat (unpubl. data).

Acknowledgements. This paper has benefited from critical comments by Russell Babcock and 3 anonymous reviewers. Research was funded by a grant from the Great Barrier Reef Marine Park Authority for studies of the recolonization of hard corals.

\section{LITERATURE CITED}

Alino, P. M., Viva Banzon, P., Yap, P. C., Gomez, E. D., Morales, J. T., Bayoneto, R. P. (1985). Recovery and recolonization on a damaged backreef area at Cangaluyan Is., Northern Philippines. Proc. 5th Int. Coral Reef Symp., Tahiti, Vol. 4: 279-284

Babcock, R. C. (1985). Growth and mortality in juvenile corals (Goniastrea, Platygyra, and Acropora): the first year. Proc. 5th Int. Coral Reef Symp., Tahiti, Vol. 4: 355-360

Babcock, R. C. (1986). A comparison of the population ecology of reef flat corals of the family Faviidae (Goniastrea, Platygyra) S. Ph.D thesis, James Cook Univ., Townsville, Australia

Babcock, R. C., Bull, G. D., Harrison, P. L., Heyward, A. J., Oliver, J. K., Wallace, C. C., Willis, B. L. (1986). Synchronous spawnings of 105 scleractinian coral species on the Great Barrier Reef. Mar. Biol. 90: 379-394

Baggett, L. S., Bright, T. J. (1985). Coral recruitment at the East Flower Garden Reef (Northeastern Gulf of Mexico). Proc. 5th Coral Reef Symp., Tahiti, Vol. 4: 379-384

Bak, R. P. M., Engel, M. S. (1979). Distribution, abundance and survival of juvenile hermatypic corals (Scleractinia) and the importance of life history strategies in the parent coral community. Mar. Biol. 54: 341-352

Birkeland, C. (1977). The importance of rate of biomass accumulation in early successional stages of benthic communities to the survival of coral recruits. Proc. 3rd Int. coral Reef Symp., Miami, Vol. 1: 15-21

Birkeland, C., Rowley, D., Randall, R. H. (1982). Coral recruitment patterns at Guam. Proc. 4th Int. Coral Reef Symp., Manila, Vol. 2: 339-344

Brock, R. E. (1979). An experimental study of the effects of grazing by parrotfishes and the role of refuges in benthic community structure. Mar. Biol. 51: 381--388

Coles, S. L. (1985). The effects of elevated temperature on reef coral planula settlement as related to power station entrainment. Proc. 5th Int. Coraí Reef Symu., Tähitit, Vól. 4 : $171-176$

Fitzhardinge, R. (1985). Spatial and temporal variability in coral recruitment in Kaneohe Bay (Oahu, Hawaii). Proc. 5th Int. Coral Reef Symp., Tahiti, Vol. 4: 373-378

Goreau, N. I., Goreau, T. J., Hayes, R. L. (1981). Settling, survivorship and spatial aggregation in planulae and juveniles of the coral Porites porites (Pallas). Bull. mar. Sci. 31 (2): $424-435$

Harrigan, J. (1972). The planular and larva of Pocillopora damicornis; lunar periodicity of swarming and substratum selection behaviour. Ph.D. thesis, Univ. of Hawaii, Hawaii

Harriott, V. J. (1983a). Reproductive ecology and population dynamics in a scleractinian coral community. Ph.D. thesis, James Cook Univ., Townsville, Australia

Harriott, V. J. (1983b). Reproductive seasonality, settlement and post-settlement mortality of Pocillopora damicornis (Linnaeus) at Lizard Island, Great Barnier Reef. Coral Reefs 2: 151-157

Harriott, V. J. (1983c). Reproductive ecology of four scleractinian species at Lizard Island, Great Barrier Reef. Coral Reefs 2: 9-18

Harriott, V. J. (1985). Recruitment patterns of scleractinian corals at Lizard Island, Great Barrier Reef. Proc. 5th Int. Coral Reef Symp., Tahiti, Vol. 4: 367-372

Harrison, P. L., Babcock, R. C., Bull, G. D., Oliver, J. K., Wallace, C. C., Willis, B. L. (1984). Mass spawning in tropical reef corals. Science 223: 1186-1189

Lewis, J. B. (1974). The settlement behaviour of planulae 
larvae of the hermatypic coral Favia fragum (Esper). J. exp. mar. Biol. Ecol. 15: 165-172

Rylaarsdam, K. W. (1983). Life histories and abundance patterns of colonial corals on Jamaican reefs. Mar. Ecol. Prog. Ser. 13: 249-260

Sakai, K., Yamazato, K. (1984). Coral recruitment to artificially denuded natural substrates on an Okinawan reef flat. Galaxea 3: 57-69

Sammarco, P. W. (1983). Coral recruitment across the central Great Barrier Reef; a preliminary report. Proc. Inaug. Great Barrier Reef Conf., Townsville, p. 245-250

Sammarco, P. W., Carlton, J. H. (1982). Damselfish territorialty and coral community structure: reduced grazing and effects on coral spat. Proc. 4th Int. Coral Reef Symp. Manila, Vol. 2: 339-344

Sokal, R. R., Rohlf, F. J. (1969). Biometry. W. H. Freeman and Co., San Francisco

Stephenson, T. A. (1931). Development and the formation of colonies in Pocillopora and Porites. Part 1. Scient. Rep. Gt Barrier Reef Exped. (1928-29), Vol. 3: 113-134

Vaughan, T. W. (1959). Rearing coral colonies from coral planulae. In: Needham, J. G. (ed.) Culture methods for invertebrate animals. Dover Publications Inc., New York, p. $145-147$

Wallace, C. C. (1983). Visible and invisible coral recruitment. Proc. Inaug. Great Barrier Reef Conf,, Townsville, p. $259-261$

Wallace, C. C. (1985a). Four years of juvenile coral recruitment to five reef front sites. Proc. 5th Int. Coral Reef Symp., Tahiti, Vol. 4: 385-390

Wallace, C. C. (1985b). Seasonal peaks and annual fluctuations in recruitment of juvenile scleractinian corals. Mar. Ecol. Prog. Ser. 21: 289-298

Wallace, C. C., Bull, G. D. (1982). Patterns of juvenile coral recruitment on a reef front during a spring-summer spawning period. Proc. 4th Int. Coral Reef Symp., Manila, Vol. 2: $345-350$

Willis, B. L., Babcock, R. C., Harrison, P. L., Oliver, J. K., Wallace, C. C. (1985). Patterns in the mass spawning of corals on the Great Barrier Reef from 1981 to 1984. Proc. 5th Int. Coral Reef Symp., Tahiti, Vol. 4: 343-348

This article was presented by Professor M. Pichon; it was accepted for printing on February 27, 1987 